\title{
DAMPAK RELOKASI TERHADAP PERUBAHAN RUANG DAN SOSIAL EKONOMI MASYARAKAT PERMUKIMAN KALIJODO DI JAKARTA
}

\author{
Alfan Sutantio ${ }^{1}$, Guntur Ismawan ${ }^{2}$, M Arifandy $^{3}$, Dedi Hantono ${ }^{4 *}$ \\ Program Studi Arsitektur Universitas Muhammadiyah Jakarta ${ }^{1234}$ \\ Jl. Cempaka Putih Tengah 27 Jakarta Pusat 10510 \\ e-mail*: dedihantono@umj.ac.id
}

\begin{abstract}
ABSTRAK
Kota Jakarta Memiliki kepadatan dan kota yang sangat kompleks sehingga tidak dapat menampung seluruh kegiatan didalamnya dikarenakan semakin berkembangnnya penduduk atas berbagai aktifitas sehingga terjadinya transformasi atas kegiatan di pinggiran kota sehingga terjadinnya alih fungsi lahan yang tidak sesuai dengan ketentuan yang sudah diberlakukan oleh pemerintah Kota DKI Jakarta. Dari hal tersebut munculnnya rumusan masalah mengenai kondisi sebelum dan sesuda dari kawasan Kalijodo, serta dampak sosial ekonomi yang dihasilkan dari relokasi permukiman kawasan terbuka Kalijodo. Metode yang digunakan berupa kualitatif deskriptif Metode tersebut berupa pembahasan opini atau teori yang di gabung dari beberapa teori dengan mengacu dari beberapa jurnal, artikel ilmiah atau bentuk tulisan ilmiah lainnya. Analisis yang digunakan berupa dampak sosial ekonomi relokasi terhadap permukiman warga di kalijodo dengan di tampilkan dalam bentuk tabel serta dari hasil tersebut memiliki kesimpulan bahwa dampak relokasi Kawasan Kalijodo mendapat kehidupan yang mencukupi dan lebih baik dari sebelumnya. Penataan kawasan tersebut berdampak untuk membentuk karakter warga yang lebih bermoral dan sejahtera.
\end{abstract}

Kata Kunci : relokasi, revitalisasi, kawasan kumuh, ruang terbuka.

\section{ABSTRACT}

The city of Jakarta has a density and a very complex city so that it cannot accommodate all activities in it due to the growing population of various activities, so that there is a transformation of activities in the suburbs so that land conversion is not in accordance with the provisions that have been imposed by the DKI Jakarta City government. From this, the formulation of problems regarding the conditions before and after the Kalijodo area emerged, as well as the socio-economic impacts resulting from the relocation of the Kalijodo open area settlement. The method used is in the form of descriptive qualitative. The method is in the form of discussion of opinions or theories that are combined from several theories with reference to several journals, scientific articles or other forms of scientific writing. The analysis used is in the form of the socio-economic impact of relocation on residents' settlements in Kalijodo by displaying it in a table form and from these results it is concluded that the impact of the relocation of the Kalijodo area has a more adequate and better life than before. The arrangement of the area has an impact on shaping the character of citizens who are more moral and prosperous.

Keywords: relocation, revitalization, slum areas, open spaces.

\section{LATAR BELAKANG}

Seiring dengan pertambahan waktu maka pertumbuhan penduduk pada suatu wilayah terutama perkotaan akan mengalami peningkatan kebutuhan ruang. Kota sebagai tempat untuk berkegiatan dan berekonomi selalu mengalami perubahan dari waktu ke waktu. Faktor yang sangat berperan dalam perkembangan jumlah penduduk adalah faktor penduduk demografis dan faktor kependudukan (Aziza, 2020).

Kota Jakarta merupakan kota yang sangat kompleks hingga tidak dapat menampung seluruh kegiatan dengan semakin bertambahnya jumlah penduduk sementara luas wilayah yang ada tidak mengalami pertambahan. Tingginya aktifitas yang terjadi tidak seimbang dengan kondisi luas Kota
Jakarta yang terbatas (Hantono et al., 2018). Akibatnya terjadilah perambatan kegiatan yang posisinya di wilayah pinggiran kota yang mengalami perubahan fungsi (Prayitno, 2017).

Kawasan Kalijodo merupakan salah satu kawasan padat penduduk di Jakarta. Hal tersebut dapat terlihat dengan adanya perubahan wujud fisik dan non fisik kota yang mengalami perubahan baik secara ruang dan sosial ekonomi. Kawasan tersebut telah berubah fungsi menjadi pemukiman ilegal yang padat dan kumuh. Pada beberapa tahun belakangan oleh pemerintah DKI Jakarta kawasan tersebut dilakukan revitalisasi menjadi fungsi ruang yang baru dan lebih baik. Kondisi infrastruktur tersebut membawa dampak terhadap perubahan sosial ekonomi masyarakat (Adnan et al., 2014). 
Adanya transformasi atas kegiatan di pinggiran kota menjadi salah satu penyebab terjadinya alih fungsi lahan yang tidak sesuai dengan peraturan pemerintahan (Hakim, 2020). Pengembalian pada peruntukan semula biasanya membutuhkan waktu yang cukup lama (Abdullah et al., 2012). Alih fungsi lahan yang tidak sesuai dengan peruntukan pemanfaatan ruang seperti yang diatur dalam rencana tata ruang yang ada sehingga membawa dampak terhadap kualitas visual kawasan (Hantono, 2017). Oleh karena itu pemerintah darerah sering melakukan penggusuran untuk memperbaiki kualitas visual kawasan yang telah beralih fungsi tersebut.

Menurut UU No. 26 tahun 2007 tentang Penataan Ruang dalam Pasal 66 ayat 1 mengatur beberapa hak warga terdampak bahwa masyarakat berhak untuk mendapatkan ganti rugi bila lokasi tanah dan rumahnya ada perubahan penataan ruang dengan adanya peraturan tersebut hak-hak warga masyarakat yang terdampak tidak perlu takut jika manakala pergusuran tersebut dilakukan secara tiba-tiba karena ada program sosialisasi kepada masyarakat yang terkena dampak proyek.

Dalam UU No.2 tahun 2012 tentang Pengadaan Tanah bagi Pembangunan untuk Kepentingan Umum menjelaskan bahwa pembebasan lahan perlu ada beberapa hal yang harus dilakukan pemerintah yaitu pemerintah harus berkonsultasi dengan masyarakat pemilik tanah. Bila warga menolak maka pemerintah tidak bisa melanjutkan proyek tersebut dan bila warga setuju maka ditetapkan berapa nilai ganti untung yang layak bagi tanah dan bangunan milik warga. Sebelum nilai yang disepakati itu diterima di rekening warga maka pemerintah tidak bisa menggusur warga dari rumah dan tanahnya

Dari latar belakang tersebut muncul sebuah rumusan masalah berupa pertanyaan-pertanyaan yang dijadikan sebagai tujuan dalam penulisan ini. Bagaimana kondisi spasial kawasan Kalijodo sebelum dan sesudah dilakukan revitalisasi? Apa dampak sosial ekonomi yang dihasilkan dari relokasi permukiman Kawasan Terbuka Kalijodo?

\section{METODE}

Penelitian ini menggunakan metode kualitatif dengan melakukan pendekatan deskriptif (Sugiyono, 2018). Metode tersebut berupa pembahasan opini atau beberapa teori yang bersumber dari beberapa jurnal atau karya tulis ilmiah lainnya. Adapun data yang akan digunakan dalam analisis nanti yang akan dibahas menggunakan data sekunder atau sebuah data yang diambil dari data bentuk tulisan, berita, perundang-undangan atau bentuk platform informasi lainnnya.

Selama masa pandemi ini maka data didapat dari literatur dan observasi seadanya untuk menghindari kontak dengan lingkungan luar sesuai dengan anjuran pemerintah. Perubahan dicatat dari kondisi sebelum relokasi dan sesudah relokasi dengan memperhatikan aspek keruangan dan sosial ekonomi.

\section{HASIL DAN PEMBAHASAN}

Kalijodo adalah daerah lama yang telah menjadi tempat tinggal masyarakat Kalijodo sebelum terjadinya relokasi lahan pemerintah. Karena adanya perubahan peraturan yang baru diterapkan membuat perlu diadakannya relokasi Sementara Marunda adalah tempat baru yang telah disediakan oleh pemerintah DKI Jakarta untuk kegiatan relokasi tersebut. Dengan adanya pergusuran yang terjadi, banyak sekali perubahan baik itu kondisi sosial mmaupun ekonomi yang telah berubah (Widayanti et al., 2013). Dampak sosial dan ekonomi menjadi fokus pembahasan, namun sebelumnya akan dianalisis kondisi objektif warga tergusur yang menempati rumah susun tersebut.

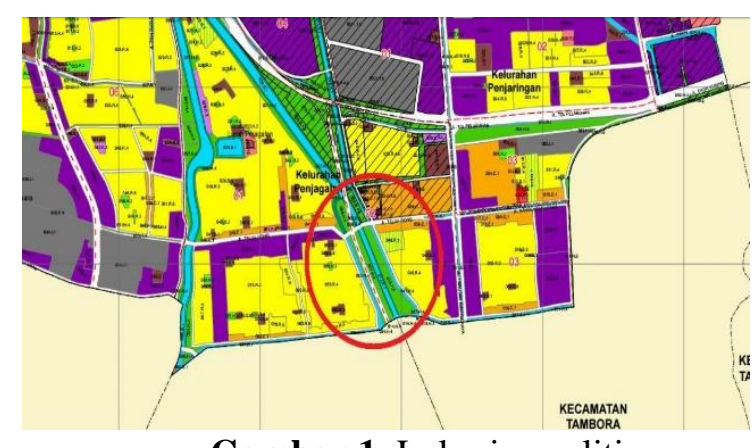

Gambar 1. Lokasi penelitian

\section{Penggusuran di Kalijodo dan Alih Fungsi Ruang Terbuka Hijau (RTH )}

Awal mulanya bangunan di Kalijodo dimana bangunannya berdiri dan bersifat semi permanen dengan di jadikan warung-warung berbagai aneka makanan layaknya pasar informal (Rafsyanjani et al., 2020). Dari tahun ketahun kemudian bangunan berubah menjadi kafe-kafe dan bangunan tersebut menjadi permanen. Kemudian kawasan itu berkembang menjadi tempat prositusi dan perjudian sekaligus menjadi tempar permukiman. Selain pelanggaran penggunaan lahan, pembangunan di jalur hijau atau lahan hijau ini juga menimbulkan berbagai masalah sosial akibat aktivitas-aktivitas yang melanggar norma-norma sosial dan agama yang berada di kawasan ini (Kurniadi et al., 2012). 
Lahan sendiri menjadi sala satu sumber daya sangat sulit untuk diperoleh untuk pembangunan sarana kawasan salasatunya RPTRA yang betujuan untuk area publik terintegrasi dalam melayani berbagai usia, yang dimana berfungsi sebgai ruang terbuka hijau, sarana pengembangan untuk anak dan sebagai pemberdayaan masyarakat. Dikarenakan lahan lahan publik tidak terbangun berupa ruang-ruang terbuka hijau (RTH). Di kawasan permukiman padat untuk keberadaan ruang terbukan hijau (RTH) sangat sedikit dan sempit. Upaya pemerintah dalam mendapatkan lahan adalah pertama dengan mencari aset-aset pemprov DKI Jakarta. Kedua, melakukan penggusuran untuk lahan-lahan pemprov DKI yang selama ini diokubasi secara ilegal. Ketiga, membeli lahanlahan yang dimiliki masyarakat. Yang kedua cara terakhir membutukan biaya yang cukup banyak. Untuk mengembalikan ruang-ruang terbuka hijau di kawasan kalijodo yang dimana selama ini dialihkannya fungsi dari ruang terbuka menjadi permukiman warga. Pemprov DKI Jakarta melakukan penggusuran dan pembongkaran bangunan-bangunan warga yang telah terbangunnya permukiman menjadi RTH dan RPTRA beserta fasilitasnya.

Dalam konflik pergusuran ini dapat terjadi karena adanya kepentingan yang dimiliki oleh kelompok superordinasi dan kelompok subordinasi. Masyarakat di Kalijodo ini harus dan patuh terhadap proses perubahan dan keteraturan baik terhadap perundang-undangan dan peraturan pemerintahan yang diberlakukan.

\section{Kondisi Lingkungan Kalijodo Sebelum Dilakukannya Pergusuran}

Lingkungan merupakan faktor utama yang mempengaruhi pembentukan serta perkembangan perilaku individu, baik secara fisik maupun nonfisik sosio psikologis yang dilakukan manusia. Penelitian ini, akan meninjau mengenai lingkungan yang dirasakan oleh masyarakat Kalijodo baik di tempat sebelumnya dan tempat yang sudah disediakan oleh Pemerintah provinsi DKI Jakarta yaitu Rumah Susun Marunda yang berada di Kecamatan Cilincing Kota Jakarta Utara.

Sebelum dilakukannya pergusuran oleh Pemprov DKI Jakarta, Wilayah Kalijodo yang dahulu dianggap telah meresahkan warga dengan kegiatan kesehariannya yang jauh melenceng dari norma agama dan hukum serta dukungan dari warga setempat untuk wilayah Kalijodo di relokasi menjadi tempat yang lebih nyaman dan berguna untuk setiap kalangan. Kawasan Kalijodo sebelumnya, tumbuh dan berkembang menjadi kawasan ditengah kota Jakarta yang padat penduduk dan terlihat sangat kumuh.

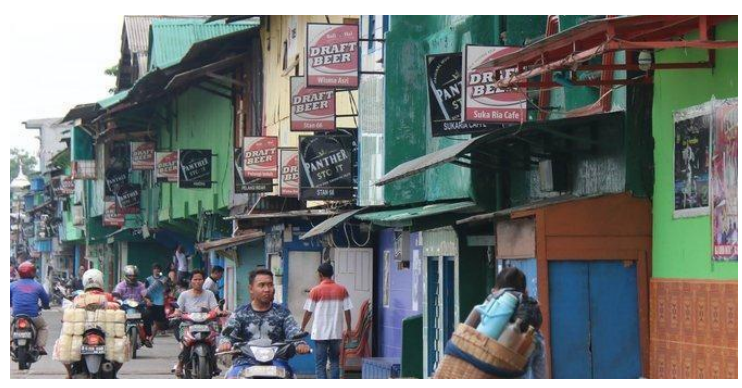

Gambar 2. Lokasi Kalijodo sebelum direlokasi Tahun 2016

Rata-rata bangunan yang telah berdiri kokoh diatas tanah tersebut, kurang lebih 60 bangunan yang setiap bangunannya telah diisi oleh para pekerja seks komersial. Bangunan yang berdiri, dilindungi oleh preman sekitar yang berjaga. Para preman yang telah ditugaskan untuk menjaga keamanan wilayah Kalijodo, mereka tidak takut mati atau rela berkorban nyawa untuk keamanan yang telah ditugaskna kepada mereka. Mereka terkenal sangat sensitif karena memiliki insting yang sangat kuat apabila terjadi hal-hal yang mencurigakan disekitar mereka.

Hal-hal tersebut memberikan dampak buruk terhadap sosial masyarakat yang ada. Berikut adalah dampak buruk yang dihasilkan pada kawasan tersebut :

1. Maraknya lapak Perjudian.

2. Banyak wanita menjadi PSK.

3. Terjadinya Perdagangan Wanita.

4. Tanah-tanah dikuasai oleh preman.

5. Sarang Narkoba.

6. Kurangnya moral pada anak-anak di kawasan tersebut.

Untuk meminimalisir kejahatan dilingkungan tersebut Pemprov DKI Jakarta langsung menindaklanjuti lokasi dengan dilakukannya pergusuran. Pergusuran tersebut dilandaskan Peraturan Daerah (Perda) Nomor 8 Tahun 2007 tentang Ketertiban Umum, Perda Nomor 7 Tahun 2010 tentang Bangunan dan Wilayah, Instruksi Gubernur Nomor 68 Tahun 2014 tentang Penataan dan Penertiban di Sepanjang Kali, Saluran, dan Jalan Inspeksi, serta Instruksi Gubernur Nomor 8 Tahun 2015 tentang Kegiatan Penertiban Umum. 


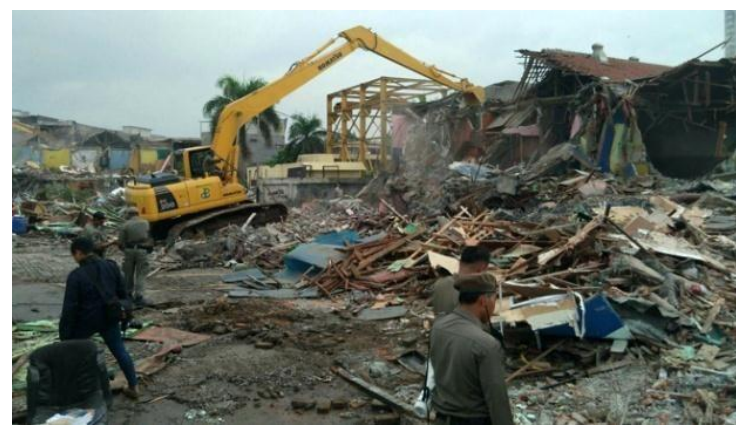

Gambar 3. Pergusuran Kawasan Kalijodo

Pergusuran yang dilakukan bertujuan untuk mengembalikan fungsi kawasan Kalijodo menjadi ruang terbuka hijau, penutupan dan penertiban kegiatan prostitusi dan peredaran minuman keras, tawaran dari Pemerintah Provinsi DKI Jakarta. Pergusuran kawasan tersebut mulai dilaksanakan sekitar tanggal 12 Februari 2016, dibarengi dengan surat edaran yang diturunkan langsung oleh Pemprov DKI Jakarta.

\section{Kondisi Lingkungan Kalijodo Setelah Dilakukannya Pergusuran dan Relokasi Tempat Tinggal}

Lingkungan yang tercipta setelah dilakukan nya pergusuran telah berubah drastis dan tampak jauh lebih baik dibandingkan kondisi sebelumnya. Rumah warga yang terkena dampak pergusuran direlokasi ketempat yang sudah disiapkan oleh Pemprov DKI Jakarta. Tempat tersebut yakni rumah susun UPRS Marunda yang berlokasi di Jakarta Utara, RT 7/7, Marunda, yang lokasi nya tidak jauh dari Kawasan Kalijodo tempat tinggal mereka sebelumnya. Berikut foto UPRS Marunda.

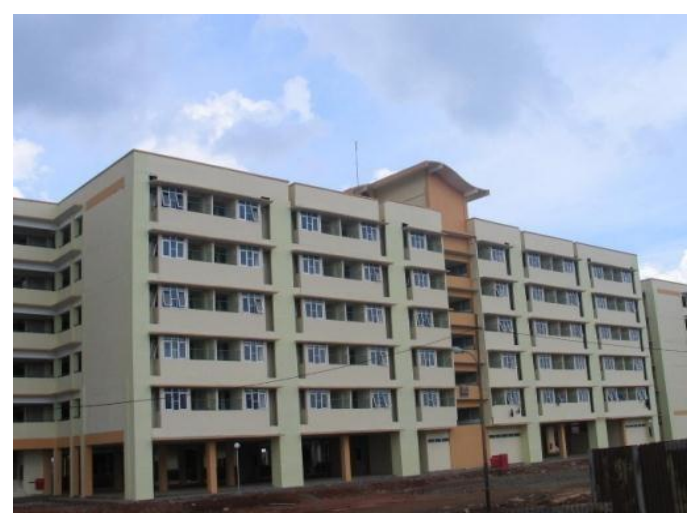

Gambar 4. Rusunawa UPRS Marunda

Kalijodo yang sekarang sudah berubah dari kawasan yang dapat dikatakan ilegal menjadi kawasan legal yang aman dan nyaman untuk ditinggali dan dinikmati. Pemprov DKI pun menyatakan serius menjadikan Kalijodo tempat yang paling nyaman di Ibu Kota. Bahkan tempat parkir kendaraan pengunjung pun ditata dan ingin dipastikan bebas dari preman. Masyarakat yang menggali rusunawa juga dipastikan dengan terjaminnya fasilitas yang mendukung dengan ditunjangnya tempat tinggal, fasilitas ruang terbuka, ruang parkir, taman dan lain-lain.

Untuk Kawasan yang mengalami pergusuran juga mengalami perubahan yang sangat drastis. Lokasi tersebut sudah dikembangkan dan dialihfungsikan sebagaimana fungsinya sesuai dengan peraturan perundangundangan yang berlaku. Penertiban dan pengamanan dilokasi tersebut, juga diperketat untuk mengurangi tingkat kejahatan yang sebelumnya sering terjadi. Seperti adanya sistem pengelolaan dan pembinaan yang dikendalikan oleh Pemkot Jakarta Utara langsung. Berikut foto sebelum dan sesudah dilakukannya pergusuran di Kawasan Kalijodo, Jakarta Utara.

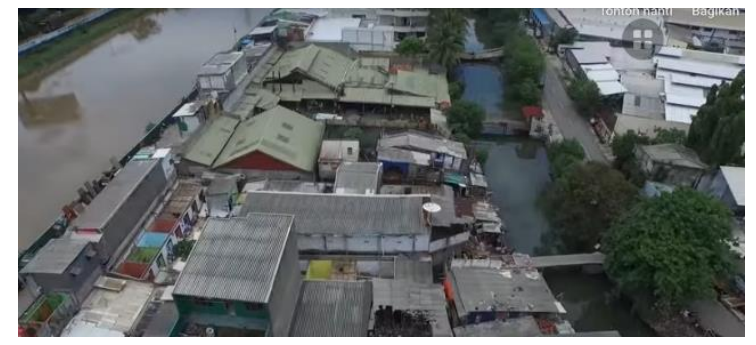

Gambar 5. Kawasan Kalijodo sebelum revitalisasi

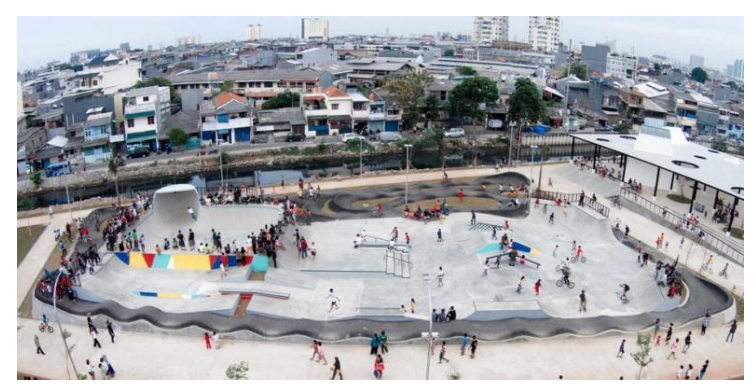

Gambar 6. Kawasan Kalijodo setelah revitalisasi

Pada gambar diatas, merupakan perubahan atas Kawasan Kalijodo terdahulu dan terkini. Setelah dilakukan nya pergusuran, kawasan tersebut benar-benar direvitalisasi dan kini kawasan tersebut dapat dinikmati oleh warga sekitar Kalijodo dan warga masyarakat luar yang ingin berkunjung. Kawasan tersebut kini telah berubah menjadi ruang terbuka atau taman yang dilengkapi dengan fasilitas olahraga seperti jalur sketcing yang mulai berkembang di era modern dan sangat disukai oleh kalangan milenial.

Untuk masalah relokasi semua masyarakat Kalijodo yang telah mendaftar bersedia untuk direlokasi akan direlokasi ke Rusun Marunda, Clincing, Jakarta Utara. 
Analisis Dampak Sosial Ekonomi Relokasi Permukiman Warga

Relokasi atau penggusuran yang dilakukan pemerintah terhadap kawasan Kalijodo memberikan sebuah dampak sosial bagi penghuni dan masyarakat di kawasan Kalijodo. Dampak sosial yang ada dan dirasakan dari adanya perbaikan moral atas penghuni kawasan yang mencoba memperbaiki kawasan tersebut.

Warga yang direlokasi dari permukiman yang tidak layak, kumuh serta banyak tindak kejahatan ke sebuah rusun yang rapi, tertata dan difasilitasi fasilitas umum memberikan sebuah dampak moral. Semua masyarakat Kalijodo yang mendaftar untuk direlokasi akan direlokasi ke Rusun Marunda, Clincing, Jakarta Utara (Permanasari \& Lientino, 2018).

Pengamatan sosial berdasar kehidupan setelah relokasi ke Rusun Marunda telah dilakukan dalam bentuk pengamatan. Hasil pengamatan yang dilaukan dirangkum dalam Tabel 1.

Tabel 1. Perubahan Ruang dan Sosial Ekonomi

\begin{tabular}{lll}
\hline Perubahan & \multicolumn{1}{c}{ Sebelum Relokasi } & \multicolumn{1}{c}{ Sesudah Relokasi } \\
\hline Ruang & $\begin{array}{l}\text { Ruang publik memanfaatkan gang-gang } \\
\text { sempit untuk bersosialisasi, bermain, dan } \\
\text { lain-lain. }\end{array}$ & $\begin{array}{l}\text { Penghuni mendapat ruang terbuka publik } \\
\text { yang baik berupa taman dan lapangan } \\
\text { olahraga. }\end{array}$ \\
\cline { 2 - 4 } & Kawasan kumuh & Rusun yang tertata rapi \\
\hline Sosial Ekonomi & Kawasan premanisme dan prostitusi & $\begin{array}{l}\text { Pemberdayaan manusia melalui pengrajin } \\
\text { batik }\end{array}$ \\
\cline { 2 - 3 } & $\begin{array}{l}\text { Sarana dan prasarana yang tidak lengkap } \\
\text { dan kurang memadai. }\end{array}$ & $\begin{array}{l}\text { Sarana dan prasarana yang semakin } \\
\text { lengkap dan baik, diantaranya: bangunan } \\
\text { pendidikan, ibadah, dan kesehatan. }\end{array}$ \\
\hline
\end{tabular}

Dalam perekonomian warga terdapat kendala. Warga sebelumnya telah mendapat penghasilan yang lebih dari pekerjaan yang kurang bagus setelah pindah penghasilannya turut berkurang. Banyak warga yang mengeluh dan belum terbiasaa akan hal tersebut. Untuk menunjang dan membantu warga di sektor perekonomian pemerintah mempunyai rencana dengan meringankan harga sewa unit dengan sebesar Rp.150.000,- sebulan. Harga tersebut lebih murah dibanding lainnya. Yang rata-rata biaya sewa Rp.500.000,- sebulan.

Lalu untuk penunjang kedua adalah dengan disediakannya gerobak untuk berjualan di sekitar rusun. Dari upaya tersebut pemerintah sudah mengupayakan kesejahteraan rakyaktnya untuk menghindari kawasan tempat tinggal yang dahulunya marak dengan tindak kejahatan. Perlahan masyarakat mulai terbiasa dengan kehidupan yang lebih bermoral dan pekerjaan yang layak.

Kalijodo telah berubah menjadi kawasan atau lingkungan yang bersahabat dengan masyarakat banyak yang sering digunakan untuk kegiatan atau aktifitas positif. Ruang terbuka yang didesain dengan arsitekturnya yang hijau dan indah merubah wajah kawasan tersebut.

\section{KESIMPULAN}

Warga dampak relokasi Kawasan Kalijodo mendapat kehidupan yang mencukupi dan lebih baik dari sebelumnya. Penataan kawasan tersebut berdampak untuk membentuk karakter warga yang lebih bermoral dan sejahtera. Walau adaptasi yang dilakukan cukup berat pada tahapannya warga tersebut bisa terbiasa dengan kehidupan baru yang lebih baik.

Kawasan Kalijodo yang dahulu merupakan tempat dengan sisi gelapnya sekarang menjadi sebuah ruang terbuka yang dapat diakses orang umum. Banyak warga atau masyarakat umum berkegiatan positif seperti berolahraga, berkekspresi, dan banyak lainnya. Desain kawasan yang ramah lingkungan juga merubah wajah kawasan Kalijodo.

Pembangunan yang berorientasi masyarakat menghasilkan produk pembangunan sesuai dengan yang dibutuhkan masyarakat pula. Oleh karena itu proyek ini dapat dijadikan percontohan bagi proyek lain yang sejenis.

\section{PUSTAKA}

Abdullah, M. S., Surjono, S., \& Rachmawati, T. A. (2012). Kesesuaian Substansi Perda RTRW Kabupaten di Provinsi Lampung. Jurnal Tata Kota Dan Daerah, 4(2), 169174.

Adnan, S., Surjono, S., \& Sutikno, F. R. (2014). Pengaruh Infrastruktur dan Kondisi Sosial Ekonomi Terhadap Ketahanan Pangan. Jurnal Tata Kota Dan Daerah, 6(1), 31-38. 
Aziza, N. (2020). Honing, Loving, and Nurturing: A Study of Mothers' Role in Family. Martabat: Jurnal Perempuan Dan Anak, $4(2)$, 251-266. https://doi.org/10.21274/martabat.2020.4.2. 251-266

Hakim, A. H. (2020). Kajian Perilaku Wisatawan dan PKL di Lapangan Merdeka Bengkulu Pada Fase Normal Baru. Jurnal Pengembangan Kota, 8(2), 188-199. https://doi.org/10.14710/jpk.8.2.188-199

Hantono, D. (2017). Pengaruh Ruang Publik Terhadap Kualitas Visual Jalan Kali Besar Jakarta. Jurnal Arsitektura, 15(2), 532-540. https://doi.org/10.20961/arst.v15i2.15114

Hantono, D., Sidabutar, Y. F., \& Hanafiah, U. I. M. (2018). Kajian Ruang Publik Kota Antara Aktivitas dan Keterbatasan. Langkau Betang: Jurnal Arsitektur, 5(2), 80-86. https://doi.org/10.26418/lantang.v5i2.29387

Kurniadi, F., Pramitasari, D., \& Wijono, D. (2012). Konsep Perilaku Teritorialitas di Kawasan Pasar Sudirman Pontianak. Vokasi, 8(3), 197-208.

Permanasari, E., \& Lientino, T. (2018). Transformasi Makna dan Fungsi Ruang di RPTRA Kalijodo dalam Pergulatan Citra Kota Jakarta. RUAS (Review of Urbanism and Architectural Studies), 16(2), 13-27. https://doi.org/10.21776/ub.ruas.2018.016.0 2.2

Prayitno, B. (2017). Integrated Sustainable Kampong Hybrid in Code Riverside Settlement in Yogyakarta, Indonesia. The 3 $R d$ International Conference on Engineering of Tarumanagara (ICET), 40-49.

Rafsyanjani, M. A., Rahmah, A. A., Wati, G. L., \& Hantono, D. (2020). Persepsi Masyarakat Terhadap Pemanfaatan Ruang di Pasar Kencar Jakarta Barat. Jurnal Arsitektur Dan Perencanaan (JUARA), 3(2), 153-159. https://doi.org/10.31101/juara.v3i2.1328

Sugiyono. (2018). Metode Penelitian Kuantitatif, Kualitatif, dan R dan D. CV. Alfabeta.

Widayanti, R., Anggraeni, M., \& Subagyo, A. (2013). Konsep Relokasi Permukiman Berdasarkan Tingkat Kerentanan di Sempadan Sungai Bengawan Solo Kecamatan Bojonegoro. Jurnal Tata Kota Dan Daerah, 5(1), 55-64. 